\title{
Factors Influencing the Decision Making of Salaried Women Employees in Banking Sector
}

\author{
K S Meenakshisundaram, K V Ramanathan
}

\begin{abstract}
Decisions towards investment are based on investor's mind set rather than rational decision making. The main objective of this research study is to identify the factors that influence the investment decisions of the women employees working in banks. The data for the study were obtained from 250 women investors employed in various banks in Chennai through survey method using a well-structured questionnaire and with. Statistical tools such as factor analysis and garrett's ranking method were used to identify the factors influencing the investment decision of the respondents. Factors like Investor's Self-confidence, Investment Prudence and Investment Planning \& Annoying Planning were identified for the investment decision of respondents. Further, Friends / Colleagues and Family members were found to be the motivational factors for influencing the decision making process by the investors.
\end{abstract}

Keywords: Investment, Investment behavior, Factor Analysis, Investment prudence, Investment planning.

\section{INTRODUCTION}

Investments are made by the investors to buy financial assets and investment decisions are taken by investors are based on their attitude and their opinions about the investments to be made. Investors are attracted to investments because they can participate in the decision-making process and see the results of their choice. The main purpose of investors engaged in investment is to maximize their income and minimize their expenses. Investors always feel that they take right investment decision, but not all investments will yield profit every time.

\section{LITERATURE REVIEW}

Mehmet Islamoglu, Mehmet Apan, Adem Ayvali (2015) in their study concluded that $i$ investors are influenced by various factors while they make investments. It was also concluded that there was significant relation between investment information and traditional behaviour on investment. It was also uncovered that there was no positive significant relation between religion and society during investment decisions. Investors think and do alternative plans to reduce their risks and gave importance to financially and further investors showed interest in knowing information on finance through media and through internet in order to do their investment.

Revised Manuscript Received on January 29, 2020.

* Correspondence Author

Dr K S Meenakshisundaram*, Director, AMET Business School, AMET University, drksmsundaram@gmail.com

Dr K V Ramanathan, Vice President, Indusind Bank, Chennai, kvram71@yahoo.com

(C) The Authors. Published by Blue Eyes Intelligence Engineering and Sciences Publication (BEIESP). This is an open access article under the CC BY-NC-ND license (http://creativecommons.org/licenses/by-nc-nd/4.0/)
Dinesh Gabhane \& Kishor S B (2013) has conveyed in their study the preferences and implication of demographics on the factors influencing the investment decision and also reveals that both genders male and female investors have preference towards fixed deposit of banks and life insurance, gold/silver, real estate, mutual fund and others. Awareness on the avenues of investment vary depending on their educational qualification. Also, investors lack awareness about investment avenues especially in company fixed deposits, debentures, fixed income bonds. Safety from the investment is the prime concern of each and every investor while taking investment decisions. Younger investor prefers to invest in investment avenues having low liquidity for longer period and elders prefer to invest in the investment avenue having higher liquidity for shorter period. Also, Investors from service sector prefer to invest for longer period with the expectation of good and safe returns while business class investors are opportunistic and preferred to invest for short period with the expectation of higher returns. Risk taking capabilities of the investors differ according to their income. In other words, Risk taking ability is directly proportional to income. Expectation of returns by the investors on investment largely depends on their capacity to invest i.e. earnings and preference of the investment avenue. Finally, has been stated that selected demographic factors were found to be significant towards the factors which influence investor's decision.

Lubna Ansari \& Sana Moid (2013) in their research study have analysed the Factors responsible for the investment behaviour of young professionals and concluded that their investment is independent of age, income and gender and further it was stated that majority of the investors before investing have considered the volatility of stock market and the risk factors.

Tomola Marshal Obamuyi (2013) has opined that investment decisions of investors in Nigeria are influenced by past performance of the company stock, dividend policy, expected stock split/capital increases/bonus, expected corporate earnings and get-rich-quick and all these factors were significantly influenced by age, gender, marital status and educational qualification of investors in the Nigerian capital market.

Sudarshan Kadariya (2012) in their study of factors affecting investor decision making in Nepalese Capital Market studied the market reactions to intangible information and tangible information.. It was reported that tangible components such as dividends, earnings,

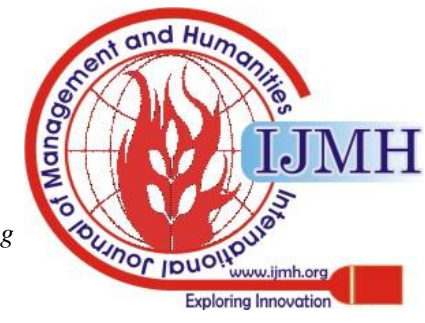


number of equity, and book to-market ratio and the intangible components like political party led government are considered the top five important factors affecting investment decisions as per the opinion of individual stock investors. The capital structure and average pricing method are found to influences the investment decisions, followed by political and media coverage, belief on luck and the financial education, and finally trend analysis. Investors believe in their ability to make profits and blame for market on incurring losses. Majority of the investors of stock prefer capital gain rather than usual cash dividends and seasonal issues. The limited investors depends on their own skills and analytical power in investment decision. The most influencing factors for decision making were found to be media and friends.

\section{OBJECTIVE OF THE STUDY}

The objective of the study are as follows:

1. To identify the factors influencing the investment decision of women working in banks.

2. To ascertain the motivational factors influencing their decision.

\section{RESEARCH METHODOLOGY}

The research Strategy followed in this research is presented below in the table.

\begin{tabular}{|l|l|}
\hline Research Design & Descriptive \\
\hline Study Population & $\begin{array}{l}\text { Working Bank Women } \\
\text { Employees }\end{array}$ \\
\hline Study Area & Chennai. \\
\hline Sample Frame & $\begin{array}{l}\text { Women Employees working in } \\
\text { Banks in the age of 21 to 60 in } \\
\text { various levels }\end{array}$ \\
\hline Sampling Unit & Employees of Bank \\
\hline Sampling Method & Convenient sampling \\
\hline Sample Size & 250 Women Investors \\
\hline Nature of Data & Both Primary and Secondary \\
\hline $\begin{array}{l}\text { Sources of Primary } \\
\text { Data }\end{array}$ & $\begin{array}{l}\text { Survey } \\
\text { Questionnaire }\end{array}$ \\
\hline $\begin{array}{l}\text { Sources } \\
\text { Secondary Data }\end{array}$ & $\begin{array}{l}\text { Journals, Magazines, Previous } \\
\text { Research Reports \& Websites }\end{array}$ \\
\hline $\begin{array}{l}\text { Tool used for Data } \\
\text { collection }\end{array}$ & Questionnaire \\
\hline Type of Questions & Close ended, Multiple choice \\
\hline $\begin{array}{l}\text { Establishing } \\
\text { Validity }\end{array}$ & $\begin{array}{l}\text { Carried out to check Validity of } \\
\text { constructed Questionnaire }\end{array}$ \\
\hline Test of Reliability & 0.810 (15 items) \\
\hline $\begin{array}{l}\text { Statistical Tools } \\
\text { Used }\end{array}$ & $\begin{array}{l}\text { Factor Analysis } \\
\text { Garrett's Ranking Method }\end{array}$ \\
\hline
\end{tabular}

\section{Data Analysis and Interpretation}

The data collected from the respondents through the structured questionnaire were consolidated and analysed. Factor Analysis technique is used to reduce the more number of variables into lesser numbers of factors.

\section{Factor analysis - Investment Belief}

In this occasion, all the 15 variables in the questionnaire relating to Investment belief were considered and factor analysis was carried out.

Table 1 showing the result of KMO and BARTLETT's Test

\begin{tabular}{l|l|r|}
\hline \multicolumn{2}{|l|}{$\begin{array}{l}\text { Kaiser-Meyer-Olkin Measure of Sampling } \\
\text { Adequacy. }\end{array}$} \\
\hline \multirow{2}{*}{$\begin{array}{l}\text { Bartlett's Test } \\
\text { of Sphericity }\end{array}$} & Approx. Chi-Square & .796 \\
\cline { 2 - 3 } & Df & 1016.005 \\
\cline { 2 - 3 } & Sig. & .000 \\
\hline
\end{tabular}

Source: Computed Data

Above table indicates the KMO measures of sampling adequacy as 0.796 which is higher than 0.5 indicates that the factor analysis can be used for the given data set. Bartlett's test of sphericity for testing the significance of the correlation of the variables indicates that the co-efficient matrix is significant as p value is 0.000 and is below 0.05 , which shows that relationships exists significantly among the variables considered for factor analysis.

Table -2 showing Communalities

\begin{tabular}{|c|c|c|}
\hline Components & Initial & Extraction \\
\hline B1. I am responsible for my Investment & 1.000 & .519 \\
\hline \begin{tabular}{|l|l} 
B2. I plan for my future. \\
\end{tabular} & 1.000 & .775 \\
\hline $\begin{array}{l}\text { B3. I have control over my financial } \\
\text { requirement. }\end{array}$ & 1.000 & .592 \\
\hline $\begin{array}{l}\text { B4. A long time investment horizon is a } \\
\text { responsibility and an advantage. }\end{array}$ & 1.000 & .592 \\
\hline $\begin{array}{l}\text { B5. Long term value creation requires } \\
\text { effective management of capital } \\
\text { savings. }\end{array}$ & 1.000 & .705 \\
\hline $\begin{array}{l}\text { B6. I will take risk only where I have a } \\
\text { strong belief that I will be rewarded for } \\
\text { it. }\end{array}$ & 1.000 & .478 \\
\hline $\begin{array}{l}\text { B7. Clear financial goals with timelines } \\
\text { and amounts should be made. }\end{array}$ & 1.000 & .383 \\
\hline $\begin{array}{l}\text { B8. I get annoyed with people who do } \\
\text { not plan in advance and save for their } \\
\text { own future. }\end{array}$ & 1.000 & 830 \\
\hline $\begin{array}{l}\text { B9. I am satisfied with my current } \\
\text { financial position }\end{array}$ & 1.000 & .487 \\
\hline $\begin{array}{l}\text { B10. I am confident of my ability to } \\
\text { select financial instruments for } \\
\text { investment }\end{array}$ & 1.000 & .597 \\
\hline $\begin{array}{l}\text { B11. I am responsible for the results of } \\
\text { my investment decisions }\end{array}$ & 1.000 & .484 \\
\hline $\begin{array}{l}\text { B12. I am confident to manage my } \\
\text { investment. }\end{array}$ & 1.000 & .508 \\
\hline $\begin{array}{l}\text { B13. I have complete knowledge of } \\
\text { available financial instruments. }\end{array}$ & 1.000 & .600 \\
\hline $\begin{array}{l}\text { B14. I feel secured and confident } \\
\text { because of my investments. }\end{array}$ & 1.000 & .511 \\
\hline $\begin{array}{l}\text { B15.I work on my own ideas without } \\
\text { depending on others in investment } \\
\text { planning. }\end{array}$ & 1.000 & .514 \\
\hline
\end{tabular}
Source: Computed Data

The communalities table identified the variance exhibited by 15 components of Investor's investment belief factors. The statements with factor loading 0.40 or higher is clustered to form separate constructs (Haier 2006) It ranges from .478 to .830 . This implies that the variance is significant in its range of $47.8 \%$ to $83.0 \%$. This further concludes that the variables grouping in the formation of factors is significant and meaningful.

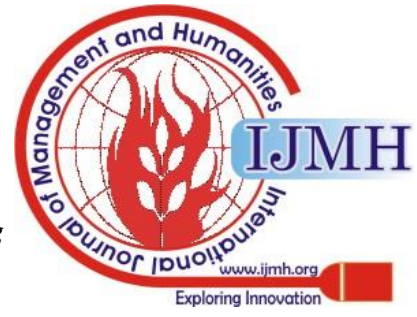


Table -3 showing Components and variance explained

\begin{tabular}{|c|l|c|c|l|}
\hline $\begin{array}{l}\text { S } \\
\text { No }\end{array}$ & Component & $\begin{array}{l}\text { Eigen } \\
\text { Value }\end{array}$ & $\begin{array}{l}\text { \% of } \\
\text { variance } \\
\text { explained }\end{array}$ & $\begin{array}{l}\text { Cum } \\
\text { Vari } \\
\text { ance }\end{array}$ \\
\hline 1 & Component 1 & 4.382 & 29.215 & 29.215 \\
\hline 2 & Component 2 & 1.857 & 12.378 & 41.593 \\
\hline 3 & Component 3 & 1.230 & 8.203 & 49.796 \\
\hline 4 & Component 4 & 1.106 & 7.372 & 57.168 \\
\hline
\end{tabular}

Source: Computed Data

The total variance amounted, for by all the four factors with Eigen value that is more than 1 is 57.17 percent and the balance variance is explained by other variables. Among the four factors, the factor one accounts for around $29.21 \%$ of variance which is the major criteria considered by any investor while evaluating an investment instrument. The second factor accounts for $12.37 \%$, third factor $8.20 \%$ and the fourth factor $7.37 \%$ of the variable which are to be considered by the investors.

Table -4 Rotated Component Matrix

\begin{tabular}{|c|c|c|c|c|}
\hline \multirow[t]{2}{*}{ Variables } & \multicolumn{4}{|c|}{ Component } \\
\hline & 1 & 2 & 3 & 4 \\
\hline $\begin{array}{l}\text { B10.I am confident of my } \\
\text { ability to select financial } \\
\text { instruments for investment }\end{array}$ & .752 & & & \\
\hline $\begin{array}{l}\text { B13.I have complete } \\
\text { knowledge of available } \\
\text { financial instruments. } \\
\end{array}$ & .737 & & & \\
\hline $\begin{array}{l}\text { B15.I work on my own ideas } \\
\text { without depending on others } \\
\text { in investment planning. }\end{array}$ & .705 & & & \\
\hline $\begin{array}{l}\text { B14.I feel secured and } \\
\text { confident because of my } \\
\text { investments. }\end{array}$ & .667 & & & \\
\hline $\begin{array}{l}\text { B12.I am confident to } \\
\text { manage my investment. }\end{array}$ & .654 & & & \\
\hline $\begin{array}{l}\text { B11.I am responsible for the } \\
\text { results of my investment } \\
\text { decisions }\end{array}$ & .589 & & & \\
\hline $\begin{array}{l}\text { B9.I am satisfied with my } \\
\text { current financial position }\end{array}$ & .529 & & & \\
\hline $\begin{array}{l}\text { B5.Long term value creation } \\
\text { requires effective } \\
\text { management of capital / } \\
\text { savings. }\end{array}$ & & .839 & & \\
\hline $\begin{array}{l}\text { B4.A long time investment } \\
\text { horizon is a responsibility } \\
\text { and an advantage. }\end{array}$ & & .742 & & \\
\hline $\begin{array}{l}\text { B6.I will take risk only } \\
\text { where I have a strong belief } \\
\text { that I will be rewarded for it. }\end{array}$ & & .637 & & \\
\hline
\end{tabular}

Retrieval Number: E0512014520/2020@BEIESP

DOI:10.35940/ijmh.E0512.024620

Journal Website: www.ijmh.org

\begin{tabular}{|l|c|c|c|c|}
\hline \multicolumn{1}{|c|}{ Variables } & \multicolumn{4}{|c|}{ Component } \\
\cline { 2 - 5 } & $\mathbf{1}$ & $\mathbf{2}$ & $\mathbf{3}$ & $\mathbf{4}$ \\
\hline B2.I plan for my future. & & & .828 & \\
\hline $\begin{array}{l}\text { B3.I have control over my } \\
\text { financial requirement. }\end{array}$ & & & .727 & \\
\hline $\begin{array}{l}\text { B1.I am responsible for my } \\
\text { Investment }\end{array}$ & & & .669 & \\
\hline $\begin{array}{l}\text { B8. I get annoyed with } \\
\text { people who do not plan in } \\
\text { advance and save for their } \\
\text { own future. }\end{array}$ & & & & \\
\hline
\end{tabular}

Extraction Method: Principal Component Analysis.

Rotation Method: Varimax with Kaiser Normalization.

a. Rotation converged in 5 iterations.

Source: Computed Data

Table 4 shows the rotated component matrix, in which the factors extracted are assigned a new name related together. First Factor is the most important factor which amounts for $29.215 \%$ of the variance where seven items are loaded on this factor. The variables are (i) I am confident of my ability to select financial instruments for investment. (B10- 0.752) (ii) I have complete knowledge of available financial instruments. (B13 - 0.737) (iii) I work on my own ideas without depending on others in investment planning. (B15 - 0.705) (iv) I feel secured and confident because of my investments. (B14 - 0.667) (v) I am confident to manage my investment. (B12 - 0.654) (vi) I am responsible for the results of my investment decisions. (B11 - 0.589) and (vii) I am satisfied with my current financial position. (B9 -0.529) are having high correlation among each other.

From above statements, it clearly shows that the investor has thorough knowledge on the financial instruments and confident on their ability to satisfy their financial requirements on her own ideas without depending on others on planning. Hence this segment of investment belief is named as Investors Self-confidence.

Factor two is the next significant factor accounted for $12.378 \%$ of the variances where three variables are loaded on this factor. These variables are (i) Long term value creation requires effective management of capital / savings. (B5-0.839) (ii) A long time investment horizon is a responsibility and an advantage. (B4 - 0.742) (iii) I will take risk only where I have a strong belief that I will be rewarded for it. (B6 - 0.637) and these items have high correlation among each other.

From these statements it is vivid that long term value creation, advantage of long term investment horizon, risk taking ability with strong belief on reward and clear financial goals would help the investor in achieving the objectives. Hence this segment of investment belief is labelled as Investment prudence.

The third factor accounted for $8.203 \%$ of variances where three items are loaded on this factor. The variables are (i) I plan for my future. (B2-0.828) (ii) I have control over my financial requirement. (B3 - 0.727) (iii) I am responsible for my investment (B1 - 0.669)

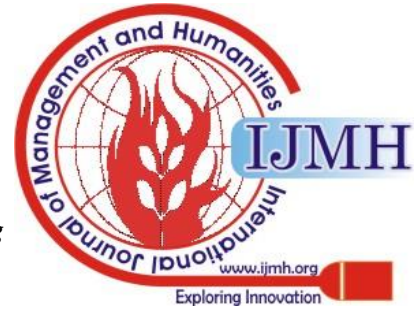


and these items have high correlation among each other. From these statements, it can be clearly understood that Investors herself is responsible for planning the investment, controlling over financial requirement. Hence this segment of investment belief can be labelled as Investment planning.

The fourth factor accounted for $7.37 \%$ of variances where only one items loaded on this factor. The variables are (i) I get annoyed with people who do not plan in advance and save for their own future. (B8 - 0.895). From this statements, it is clear that Investor is responsible for the results on his investment decision and would get irritated on person who does not plan for their future. Hence this segment of investment belief can be labelled as annoying planning.

Table 5 showing Factor loading, Eigen value, \%age of variance and Cumulative \%age of variance

\begin{tabular}{|c|c|c|c|c|c|}
\hline $\begin{array}{c}\text { Facto } \\
\text { rs }\end{array}$ & Statements & \begin{tabular}{|c|} 
Factor \\
Loadin \\
g \\
\end{tabular} & $\begin{array}{l}\text { Eigen } \\
\text { Value }\end{array}$ & $\begin{array}{c}\% \text { of } \\
\text { Varianc } \\
\text { e }\end{array}$ & $\begin{array}{l}\text { Cumulat } \\
\text { ive \% of } \\
\text { Variance }\end{array}$ \\
\hline $\begin{array}{c} \\
\text { Invest } \\
\text { ors } \\
\text { Self } \\
\text { Confi } \\
\text { dence }\end{array}$ & 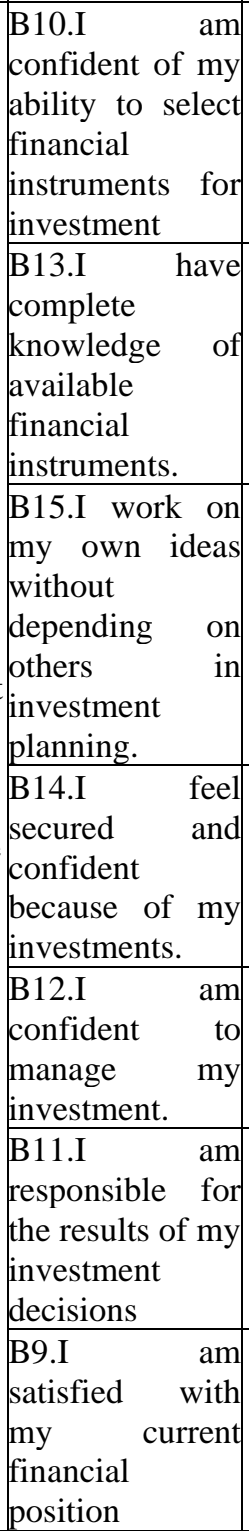 & \begin{tabular}{|l|}
.752 \\
\\
.737 \\
\\
.705 \\
.589 \\
.667 \\
\end{tabular} & 4.382 & 29.215 & 29.215 \\
\hline $\begin{array}{c}\text { Invest } \\
\text { ment } \\
\text { Prude } \\
\text { nce }\end{array}$ & $\begin{array}{l}\text { B5.Long term } \\
\text { value creation } \\
\text { requires } \\
\text { effective } \\
\text { management of } \\
\text { capital / savings. }\end{array}$ & .839 & 1.857 & 12.378 & 41.593 \\
\hline
\end{tabular}

\begin{tabular}{|c|c|c|c|c|c|}
\hline $\begin{array}{c}\text { Facto } \\
\text { rs }\end{array}$ & Statements & \begin{tabular}{|c|} 
Factor \\
Loadin \\
g \\
\end{tabular} & $\begin{array}{l}\text { Eigen } \\
\text { Value }\end{array}$ & \begin{tabular}{|c|}
$\%$ of \\
Varianc \\
e \\
\end{tabular} & \begin{tabular}{|l|} 
Cumulat \\
ive \% of \\
Variance \\
\end{tabular} \\
\hline & $\begin{array}{l}\text { B4.A long time } \\
\text { investment } \\
\text { horizon is a } \\
\text { responsibility } \\
\text { and an } \\
\text { advantage. }\end{array}$ & .742 & & & \\
\hline & $\begin{array}{l}\text { B6.I will take } \\
\text { risk only where I } \\
\text { have a strong } \\
\text { belief that I will } \\
\text { be rewarded for } \\
\text { it. }\end{array}$ & .637 & & & \\
\hline \multirow{3}{*}{$\begin{array}{c}\text { Invest } \\
\text { ment } \\
\text { Planni } \\
\text { ng }\end{array}$} & $\begin{array}{l}\text { B2. I plan for } \\
\text { my future. }\end{array}$ & .828 & \multirow{3}{*}{1.230} & \multirow{3}{*}{8.203} & \multirow{3}{*}{49.796} \\
\hline & \begin{tabular}{|lr} 
B3. I & have \\
control over \\
my financial \\
requirement.
\end{tabular} & .727 & & & \\
\hline & $\begin{array}{l}\text { B1. I am } \\
\text { responsible for } \\
\text { my Investment }\end{array}$ & .669 & & & \\
\hline $\begin{array}{c}\text { Anno } \\
\text { ying } \\
\text { Planni } \\
\text { ng }\end{array}$ & $\begin{array}{l}\text { B8. I get } \\
\text { annoyed with } \\
\text { people who do } \\
\text { not plan in } \\
\text { advance and } \\
\text { save for their } \\
\text { own future. }\end{array}$ & .895 & 1.106 & 7.372 & 57.168 \\
\hline
\end{tabular}

The table above depicts the total composition value of each factor that provides details regarding the items that constitute these four factors with the factor loadings value and Eigen values and their explained variance of each factor. The four factors accounts for $57.17 \%$ of the explained variance, which is more than $50 \%$. The four factor solution may be recommended as factors that influence the belief on investment by the investors.

\section{Garrett's Ranking - Motivational Factor}

Garrett's Rank technique was used to identify the significant motivational factors which influence the decision making process of the investors. Nine motivational sources were identified and were ranked by the respondents for this study. Friends / Colleagues, Internet/Websites / What's app, Financial News / Annual Reports, Market Reference, Financial Advisors, Family Members, Newspaper /Magazines, Radio /Television Advertisement and Leaflet / Phone calls / Sign Boards were considered as the source of information which motivates the investors in decision making process of choosing the investment. The table 6 below would show the details:

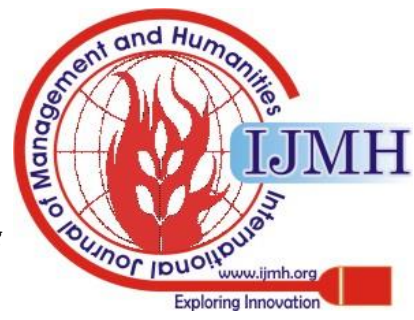


Table-6 showing the source of motivation for investment decision.

\begin{tabular}{|l|c|c|c|}
\hline $\begin{array}{l}\text { Source of } \\
\text { Motivation }\end{array}$ & $\begin{array}{l}\text { Total } \\
\text { Score }\end{array}$ & $\begin{array}{c}\text { Mean } \\
\text { Score }\end{array}$ & Rank \\
\hline Friends / Colleagues & $\mathbf{1 4 7 9 0}$ & $\mathbf{5 9 . 1 6}$ & II \\
\hline $\begin{array}{l}\text { Internet/Websites / } \\
\text { What's app }\end{array}$ & 12083 & 48.33 & VII \\
\hline $\begin{array}{l}\text { Financial News / } \\
\text { Annual Reports }\end{array}$ & $\mathbf{1 3 1 5 9}$ & $\mathbf{5 2 . 6 4}$ & III \\
\hline Market Reference & 12572 & 50.29 & V \\
\hline Financial Advisors & 12708 & 50.83 & IV \\
\hline Family Members & $\mathbf{1 5 7 9 9}$ & $\mathbf{6 3 . 2 0}$ & I \\
\hline $\begin{array}{l}\text { Newspaper } \\
\text { /Magazines }\end{array}$ & 12192 & 48.77 & VI \\
\hline $\begin{array}{l}\text { Radio /Television } \\
\text { Advertisement }\end{array}$ & 10200 & 40.80 & VIII \\
\hline $\begin{array}{l}\text { Leaflet / Phone calls / } \\
\text { Sign Boards }\end{array}$ & 8997 & 35.99 & IX \\
\hline
\end{tabular}

Table - 6 above reveals the Garrett ranking results for the source of motivational factors of the respondents. It is evident that Friends / Colleagues have been ranked as first motivational factor followed by family members taking the second position. Third and fourth positions were taken by Financial News / Annual reports and financial advisors respectively. Market reference and Newspapers /Magazines have taken the fifth and sixth ranks chosen by the investors. Internet/Websites / what's app has taken the seventh position and the last two positions were taken by Radio /TV Advertisement and Leaflet / Phone calls / Sign Boards respectively.

\section{CONCLUSION}

This study primarily aimed to identify those factors which have a bearing on the investment belief and the motivational factors. The four factors extracted by the researcher represents the decision making factors of the women employees working in banks. These factors are Investors self-confidence, Investment prudence, Investment planning and Annoying planning. Among the source of motivation friends and colleagues along with family members have influence in the decision making of salaried women employees working in banking sector.

\section{REFERENCES}

1. Anitha, D and Bhargavi, Phani (2014), "Investor's Perception Towards Investment", Global Journal of Finance and Management, Vol. 6, No. 2, 2014, pp. 185-190.

2. Chaturvedi, Meenakshi and Khare, Shruti. (2013), "Study of Saving Pattern and Investment Preferences of Individual Household in India", International Journal of Research in Commerce \& Management, Vol. 3, Issue 5, pp. 115-120.

3. Dinesh Gabhane \& Kishor S B, (2013) "Preferences and significance of demographics on the factors influencing investment decisions: A study of investors in Thane City, Maharashtra”, International Journal of Research in Commerce, IT and Management, Volume 3, Issue 7, Jul 2013, ISSN 2231-5756, pp.44-48.

4. Gaurav Kabra, Prashant Kumar Mishra \& Manoj Kumar Dash, "Factors influencing Investment Decision of generations in India : An Econometric study", Asian Journal of Management, Review Article, ISSN 2229-3795, pp.308-326.
5. Lubna Ansari \& Sana Moid, (2013) "Factors affecting investment behaviour among young professionals", International Journal of technical Research and Applications, e-ISSN: 2320-8163, Vol.1,Issue 2, (May-June 2013), pp-27-32

6. Mehmet Islamoglu, Mehmet Apan, Adem Ayvali, (2015) "Determinations of factors affecting individual investor behaviours: A study on Bankers", International journal of Economics and Financial Issues, IJEFI, 2015, Vol5, Issue -2, ISSN: 2146-4138, pp.531-543.

7. Panda B N \& Panda J K, (2013) “A comparative study on relevance of demographic factors in Investment decision: A study on employees of education sector", JBMCR, Journal for business management, Commerce \& Research, Vol-I, No.4, Jun 2013, ISSN 2319-250X)

8. Rajkumar S \& Venkatramaraju D, (2014) "A study on factors influencing individual investors towards IPOs Performance", International Journal of Business and Administration Research Review, IJBARR, Vol.1, Issue 7, Oct-Dec, 2014, pp.79-82, E-ISSN-2347-856X (Online), ISSN2348-0653.

9. Saugat Das \& Ritika Jain, (2014) "A study on the influence of demographical variables on the factors of investment - A perspective on the Guwahati region", International Journal of Research in Humanities, Arts \& Literature, IJRHAL, Vol.2, Issue 6, June 2014, ISSN (P) 2347-4564, ISSN (E) 2321-8878, pp.97-102.

10. Seetharaman A, Indu Niranjan, Nitin Patwa \& Amit Kejriwal, (2017) "A study of the factors affecting the choice of investment portfolio by individual investors in Singapore", Accounting and Finance Research, Volume 6, Issue 3, Aug 2017, ISSN 1927-5986, pp.153-168

11. Sellappan R, Jamuna S \& Kavitha TNR, (2013) "Investment attitude of women towards different source of securities - A Factor analysis approach", Global Research Analysis, GRA, Volume 2, Issue 2, Feb 2013, ISSN 2277-8160,pp.34-36.

12. Shanmugasundaram V \& Jansi rani N, (2012) "Influential factors in investment decision making", South Asian Journal of Marketing \& Management Research (SAJMMR), Volume 2, Issue 6, (June 2012), ISSN: 2249-877X, pp.96-106.

13. Sudarshan Kadariya, (2012) "Factors affecting investor decision making: A case of Nepalese Capital Market", Journal of research in Economics and International Finance (JREIF) Vol.1, pp.16-30, July 2012.

14. Tai-Yuen Hon, (2012), "The behaviour of small investors in the Hong Kong Derivatives Market: A factor Analysis", Journal of Risk \& Financial Management, ISSN 1911-8074, pp.59-77.

15. Tomola Marshal Obamuyi, (2013) "Factors influencing investment decisions in capital market: A study of individual investors in Nigeria", Organizations and markets in emerging economies, 2013, Vol.4, No.1(7), ISSN: 2029-4581, pp.141-161

16. Vidyakala K, Nakhala Devi \& Iswarya Rani G, (2015) “An analysis on factors affecting buying behaviour towards financial instruments with special reference to Trichy District", International Journal of applied Research, IJAR, Volume 1, Issue 9, ISSN 2394-7500,pp.754-757.

17. Vijaya E, (2014) "Influential factors on Investment behaviour of individual Investors: A Review of empirical evidences from various countries", International Research Journal of Management and Commerce, Volume 1, Issue 5, Aug 2014, ISSN: 2348-9766, pp.35-46.

18. Viswanadham N, Edward N, Dorika \& Mwakapala D, (2014) "A study of perceptual factors influencing investors buying behaviour in Tanzanian Equity Market, Journal for Finance and Investment Analysis, Vol.3, No.2, 2014, pp-99-108, ISSN: 2241-0998 (print version), 2241-0996 (Online).

\section{AUTHORS PROFILE}

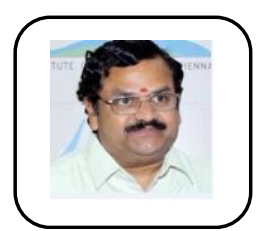

Dr K S Meenakshisundaram - Director, AMET Business School, AMET University, Chennai Best Academic Performer and Administrator Award from Association of Management Professionals on 16.06.2019 in Hyderabad Best Academic Administrator Award (in the category of Management) 2015 awarded by The Director, VENUS International Foundation, Chennai. Ph.D (Management Studies), Ph.D(Agricultural Extension), M.B.A(Marketing Management), M.B.A.(Personnel Management), M.Sc. (Agricultural Extension), B.Sc. (Agriculture), Post graduate Diploma in Journalism and Mass communication, Post graduate Diploma in Training and Development Training \& Development, Diploma in Software Technology Software Technology, Post graduate Diploma in Business Management.

Published By:

Blue Eyes Intelligence Engineering \& Sciences Publication

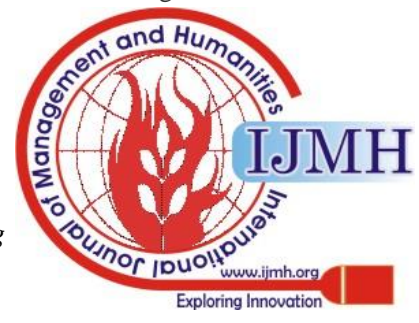


A multi-faceted seasoned professional having over 39 years of rich \& dynamic experience in Teaching, General Management / Personnel Administration/ Training \& Development / HRM and Faculties Management across industry verticals. Hands on experience in general administrative activities, personnel management, corporate policy implementation and facilities management across assignments. Result oriented, dynamic, timely accurate reporter. Served as an Expert Member in Cauvery Technical cell water dispute. External Examiner, Vellore Institute of Technology for Department of Management Studies. Member Board of Selection for SCSVMV University Kancheepuram, Sathyabama University. Member Doctoral committee in Anna University, Chennai. Member Doctoral committee in Dr. M.G.R. University Chennai. External Examiner for PhD and M.Phil. for Bharathiyar University, Coimbatore. External Examiner for SRM and Kanchi University. Member Doctoral Committee Saveetha University. External Examiner, Bharath University, Chennai. Associated with 93 journals in the Editorial board. I have published more than 35 papers in the international journals and more than 12 papers in National journals. Besides presented several papers in the National and International conferences and 4 of my scholars completed doctorates and three are doing.

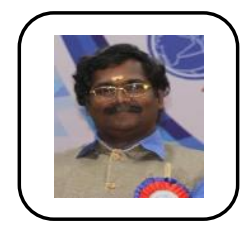

Dr K V Ramanathan - Vice President - Internal Audit - Indusind Bank, Chennai

FCA, FCMA, Ph.D M.Com, MBA (Finance), M.Phil

(Commerce), MA (Public Administration), MA (Personnel Management \& Industrial Relation), BGL, PG Diploma in International Business, PG Dip in Foreign Trade, PG Dip in Intellectual Property Rights, PG Dip in Financial Management. A seasoned finance and audit professional with over 25 years of experience in Manufacturing and Banking Industry. He has expert knowledge in Accounting, Internal Audit, Risk Management, Taxation, Legal and secretarial aspects of Bank. Very good in developing and motivating the team spirit towards Mission objectives. He is a fellow member of the Institute of Chartered Accountants of India and a fellow member of Institute of Cost \& Management Accountants of India. He also possess a Doctorate in Management from Sri Chandrasekharendra Saraswathi Viswa Mahavidyalaya. He holds Master Degree in Commerce, Public Administration, Personnel Management \& Industrial relation and Business Administration (Finance). He also hold M.Phil in Commerce and also Graduate Degree in General Law. He has cleared SEVEN Post Graduate Diplomas in various fields including International Business, Taxation, Foreign Trade and Intellectual Property Rights. He holds 12 Certification including Trade Finance, AML/KYC, Digital Banking, Quantitative Methods, BCSBI, Cyber crime and Fraud Management IT Security and Foreign Exchange from Indian Institute of Banking and Finance. He also hold licentiate from Insurance Institute of India. He is a gold medalist in Intellectual Property Rights. As a researcher he has published and presented more than 20 research articles in various international journals. He was an Adjunct faculty in VIT Vellore and also guest lecturer in various business schools and colleges in Chennai.

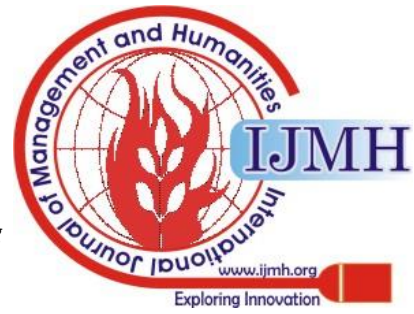

